\title{
FAKTOR YANG MEMENGARUHI KUNJUNGAN MASYARAKAT DALAM PEMANFAATAN POSBINDU PENYAKIT TIDAK MENULAR DI WILAYAH KERJA PUSKESMAS SINGKIL UTARA TAHUN 2019
}

\author{
Yenny Mawaddah ${ }^{1)}$, Nuraini ${ }^{2}$, Linda Hernike Napitupulu $^{3)}$ \\ 1)Program Studi S2 IImu Kesehatan Masyarakat, Institut Kesehatan Helvetia \\ ${ }^{2}$ Fakultas Kesehatan Masyarakat, Institut Kesehatan Helvetia \\ Email: yenny.mawaddah@gmail.com
}

\begin{abstract}
ABSTRAK
Penyakit tidak menular telah menjadi masalah kesehatan masyarakat dan dapat dicegah dengan mengendalikan faktor risikonya melalui program Posbindu yang sampai saati kunjungan masyarakat di bawah 100\%. Hasil rekapitulasi kunjungan PTM di Puskesmas Singkil Utara tahun 2016 sebanyak 496 orang (3 Posbindu) tahun 2017 sebanyak 958 (16,3\%) dari jumlah sasaran 5.891 orang (7 Posbindu PTM) dan tahun 2018 periode Januari sampai Juli 2018 sebanyak 2.012 orang $(32,7 \%)$ dari 6.152 . Tujuan penelitian adalah untuk menganalisis pengaruh faktor pekerjaan, pengetahuan, sikap, dukungan tenaga kesehatan, dukungan kader, dukungan keluarga dan dukungan tokoh masyarakat terhadap kunjungan masyarakat dalam pemanfaatan Posbindu di Wilayah Kerja Puskesmas Singkil Utara Tahun 2019.

Jenis penelitian adalah kualitatif menggunakan desain Case Control. Populasi sebanyak 134 orang dengan sampel sebanyak kasus sebanyak 134 dan kontrol (tidak obesitas) 134 orang diambil dengan maching jenis kelamin dan umur. Teknik pengumpulan data menggunakan kuesioner. Data dianalisis dianalisis secara univariat, bivariat dan multivariat menggunakan uji regresi logistik berganda pada taraf kemaknaan 95\%.

Faktor pengetahuan, sikap, dukungan tenaga kesehatan, dukungan kader, dan dukungan keluarga pengaruh terhadap kunjungan dalam pemanfaatan posbindu dan memengaruhi sebesar $79 \%$. Faktor dukungan keluarga dominan memengaruhi dengan nilai Exp (B) sebesar 9,150. Faktor pekerjaan dan dukungan tokoh masyarakat tidak pengaruh

Untuk merubah pengetahuan, sikap, dukungan tenaga kesehatan, dukungan kader, dan dukungan keluarga maka Puskesmas Singkil Utara menyelenggarakan pelatihan tengang komunikasi kepada kader secara kontrinyu, membantu dalam mendukung fasilitas kesehatan dalam deteksi dini PTM. Kader diharapkan memberikan penyuluhan tentang program PTM secara kontinyu dan menambah berbagai kegiatan lainnya seperti masak-memasak dan senam untuk meningkatkan ketertarikan masyarakat.
\end{abstract}

Kata Kunci : Loyalitas, Pasien Rawat Inap

Copyright (C) 2020 Jurnal Skala Kesehatan. Politeknik Kesehatan Banjarmasin All rights reserved

Corresponding Author:

Yenny Mawaddah,

Program Studi S2 IImu Kesehatan Masyarakat, Institut Kesehatan Helvetia Email :

yenny.mawaddah@gmail.com 


\section{PENDAHULUAN}

Pos Pembinaan Terpadu (Posbindu) merupakan peran serta masyarakat dalam melakukan kegiatan deteksi dini dan pemantauan faktor risiko Penyakit Tidak Menular (PTM) yang dilaksanakan secara terpadu, rutin, dan periodik. Faktor risiko penyakit tidak menular meliputi merokok, konsumsi minuman beralkohol, pola makan tidak sehat, kurang aktifitas fisik, obesitas, stres, hipertensi, hiperglikemi, hiperkolesterol serta menindak lanjuti secara dini faktor risiko yang ditemukan melalui konseling kesehatan dan segera merujuk ke fasilitas pelayanan kesehatan dasar.

Data World Health Organization (WHO) menunjukkan bahwa sebanyak 57 juta (63\%) angka kematian yang terjadi di dunia dan 36 juta (43\%) angka kesakitan disebabkan oleh penyakit tidak menular. Global status report on NCD WHO tahun 2010 melaporkan bahwa $60 \%$ penyebab kematian semua umur di dunia adalah karena penyakit tidak menular dan $4 \%$ meninggal sebelum usia 70 tahun. Seluruh kematian akibat penyakit tidak menular terjadi pada orang-orang berusia kurang dari 60 tahun, 29\% di negara-negara berkembang, sedangkan di negara-negara maju sebesar $13 \%$ (1).

Berdasarkan penelitian yang dilakukan Kemenkes $\mathrm{Rl}$ yang tertuang dalam Riset Kesehatan Dasar (2013), kasus PTM terus meningkat setiap tahunnya tercatat prevalensi penyakit hipertensi $26,5 \%$, rematik $24,7 \%$, asma $4,5 \%$, penyakit paru kronik obstruktif $3,7 \%$, diabetes melitus $2,1 \%$, penyakit jantung koroner $1,5 \%$, stroke $1,2 \%$, batu ginjal $0,6 \%$, gagal jantung $0,3 \%$, gagal ginjal $0,2 \%$, kanker $0,1 \%(2)$.

Prevalensi Penyakit tidak menular di Provinsi Aceh cukup tinggi. Laporan Profil Penyakit Tidak Menular Departemen Pencegahan dan Pengendalian PTM berdasarkan Persentase Pengunjung Posbindu PTM Tahun 2016 bahwa jumlah penderita hipertensi 2.223 orang $(42.4 \%)$, dari 5.237 orang diperiksa, diabetes melitus 433 dari 893 yang diperiksa (48.5\%). Berdasarkan kriteria kasus dirawat inap di rumah sakit se Indonesia bahwa Provinsi Aceh dengan penyakit rematoid artirits 236 kasus, gagal jantung 6.573 orang, ginjal 1.125 kasus dan kanker 254 kasus (3).

Salah satu kegiatan pengendalian dan pencegahan penyakit tidak menular yang dilakukan pemerintah yaitu monitoring dan deteksi dini penyakit hipertensi melalui program Posbindu PTM. Posbindu PTM adalah salah satu program Upaya Kesehatan Bersumber Daya Masyarakat (UKBM) dan merupakan salah satu tuntutan dari Undang-Undang Kesehatan RI Nomor 36 Tahun 2009 Bab X Pasal 158 bahwa pemerintah, pemerintah daerah, dan masyarakat melakukan upaya pencegahan, pengendalian, penanganan PTM beserta akibat yang ditimbulkan (4).

Jumlah kunjungan Posbindu PTM di Kabupaten Singkil belum mencapai target nasional 100\%. Kabupaten Singkil mempunyai wilayah kerja terdiri dari 12 puskesmas dengan masing-masing kunjungan Posbindu tahun 2017 berturut-turut yaitu 1) Puskesmas Singkil 37,5\%, 2) Puskesmas Simpang Kanan 37,1\%, 3) Puskesmas Kuala Baru 36,1\%, 3) Puskesmas Singkohor 34,7, 4) Puskesmas Pulau Banyak 34,4\%, 5) Puskesmas Pulau Banyak Barat 34,3\%, 6) Puskesmas Danau Paris 33,7\%, 7) Puskesmas Gunung Meriah $32,8 \%$, 8) Puskesmas Kuta Baharu 32,4\%, 9) Puskesmas Kuta Tinggi 32,9\%, 10) Puskesmas Suro 31,6\%, 11) Puskesmas Singkil Utara 16,3\%. Jumlah Kunjungan Posbindu paling rendah adalah di Puskesmas Singkil Utara yaitu 16,3\% disebabkan kurangnya pemahaman masyarakat tentang pelayanan Posbidu sebagai alasan peneliti menentukan tempat penelitian (5).

Perilaku seseorang berkunjung ke tempat pelayanan kesehatan ditentukan oleh tiga faktor, yaitu faktor predisposisi (antara lain pengetahuan, sikap, kepercayaan, nilai, karakteristik individu), faktor pemungkin (antara lain ketersediaan sarana kesehatan, jarak tempuh, hukum pemerintah, keterampilan terkait kesehatan), dan faktor penguat (antara lain keluarga, teman sebaya, guru, tokoh masyarakat) (6).

Faktor lainnya penyebab rendahnya perilaku masyarakat dalam memanfaatkan Posbindu sebagaimana menurut teori Green menjelaskan bahwa perilaku merupakan faktor kedua terbesar setelah faktor lingkungan yang memengaruhi kesehatan individu kelompok 
atau masyarakat. Perilaku dipengaruhi oleh tiga faktor utama yaitu: faktor predisposisi, faktor pendukung dan faktor pendorong. Oleh karena itu upaya untuk mengubah perilaku masyrakat dalam memanfaatkan Posbindu tidak mudah untuk dilakukan. Perubahan perilaku yang tidak didasari oleh pengertian dan kesadaran yang tinggi tidak akan bertahan lama (11).

Hasil survei awal di wilayah kerja Puskesmas Singkil Utara bahwa Posbindu PTM telah dijalankan sejak tahun 2014 sampai sekarang. Kegiatan Posbindu PTM dilakukan secara berkala melalui sistem 5 meja, yaitu pendaftaran; wawancara; pengukuran berat badan (BB) dan analisa lemak tubuh; pengukuran tekanan darah dan gula darah; serta konseling, edukasi, dan tidak lanjut lainnya. Peserta Posbindu PTM akan dipantau melalui KMS-FR PTM (Kartu Menuju Sehat Faktor Resiko Penyakit Tidak Menular) sehingga monitoring dan deteksi dini penyakit tidak menular dapat dilaksanakan. Program Posbindu diselenggarakan sesuai dengan Keputusan Menteri Kesehatan bahwa setiap kegiatan Posbindu harus mencapai target $100 \%$, artinya bahwa setiap Posbindu dapat menskrining faktor risiko penyakit tidak menular kepada seluruh masyarakat selama 5 tahun di wilayah kerjanya.

Puskesmas Singkil Utara terdiri dari 7 desa dan memiliki Posbindu PTM sebanyak 7 Posbindu. Pelaksanaan Posbindu PTM di wilayah kerja Puskesmas Singkil Utara dilaksanakan 1 kali dalam sebulan dengan melibatkan 6 petugas sebagai pelaksana program yaitu 1 petugas puskesmas terkait dan 5 kader. Waktu pelaksanaan Posbindu PTM sama seperti posyandu balita yaitu pukul 10.00 WIB sampai dengan 13.00 WIB. Hasil laporan rekapitulasi PTM di Puskesmas Singkil Utara bahwa jumlah masyarakat yang berkunjung ke Posbindu tahun 2015 sebanyak 274 orang (3 Posbindu), tahun 2016 sebanyak 496 orang (3 Posbindu) tahun 2017 sebanyak 958 (16,3\%) dari jumlah sasaran 5.891 orang (7 Posbindu PTM). Pada tahun 2018 jumlah masyarakat yang pernah berkunjung periode Januari sampai Juli 2018 sebanyak 2.012 orang $(32,7 \%)$ dari 6.152 orang penduduk usia di atas 15 tahun dan rata-rata perbulan 287 orang (7 Posbindu PTM). Ini mengindikasikan bahwa kunjungan masyarakat mengalami peningkatan dibandingkan tahun sebelumnya tetapi belum mencapai target sasaran $100 \%$. Penyakit tidak menular diderita masyarakat yang paling banyak ditemukan adalah hipertensi, rematik, gastritis, kolesterol dan diabetes melitus.

Hasil wawancara dengan 10 orang masyarakat yang rutin berkunjung ke Posbindu PTM berumur di atas 30 tahun (30\%) dengan pendapatan yaitu Rp. < 2 juta (30\%) dan berpendidikan SMP dan SMA (30\%) serta memiliki pekerjaan wiraswasta/petani/nelayan $(60 \%)$. Masyarakat rutin berkunjung ke Posbindu dengan alasan ingin mengetahu tentang jenis-jenis penyakit tidak menular dan penyebabnya (60\%), merasakan manfaat Posbindu $(70 \%)$, ingin mengetahui penyakit tidak menular pada tubuhnya $(70 \%)$, jarak tidak menjadi halangan datang ke Posbindu PTM (50\%), petugas kesehatan mempromosikan Posbindu kepada masyarakat (50\%), kader juga menginformasikan tentang jadwal Posbindu setiap bulan (60\%), keluarga mendukung agar anggota keluarga berkunjung ke Posbindu (40\%), dan tokoh masyarakat aktif berpartisipasi mensukseskan program Posbindu PTM (30\%)

Hasil wawancara dengan 10 orang masyarakat yang jarang berkunjung ke Posbindu PTM diketahui bahwa dengan alasan yaitu berumur di bahwa 30 tahun (40\%) dengan pendapatan yaitu Rp. > 2 juta (40\%) dan berpendidikan SMA/ Sarjana (40\%) serta memiliki pekerjan sebagai pegawai kantoran (60\%). Masyarakat jarang berkunjung ke Posbindu dengan alasan tidak ingin mengetahu tentang jenis-jenis penyakit tidak menular dan penyebabnya $(80 \%)$, tidak ingin mengetahui penyakit tidak menular pada tubuhnya $(60 \%)$, jarak menjadi halangan datang ke Posbindu PTM (80\%), petugas kesehatan kurang mempromosikan Posbindu kepada masyarakat $(60 \%)$, kader juga tidak menginformasikan tentang jadwal Posbindu setiap bulan (60\%), keluarga kurang mendukung agar anggota keluarga berkunjung ke Posbindu (60\%), dan tokoh masyarakat tidak aktif berpartisipasi mensukseskan program Posbindu PTM (70\%). 
Berdasarkan identifikasi masalah rendahnya kunjungan Posbindu di Puskesmas Singkil Utara disebabkan rendahnya pengetahuan masyarakat tentang manfaat Posbindu karena tingkat pendidikan masyarakat rendah, tidak ada waktu karena sebagian memiliki pekerjaan, jarak menjadi faktor penghalang datang ke Posbindu, peran atau dukungan tenaga kesehatan kurang memberikan dorongan dan promosi tentang kegiatan Posbindu, dukungan kader belum aktif menginformasikan kegiatan Posbindu serta tokoh masyarakat kurang aktif dalam berpartisipasi mensukseskan program Posbindu yang ada di desa. Kondisi inilah yang menjadi alasan peneliti mengkaji tentang faktor yang memengaruhi kunjungan masyarakat ke Posbindu.

Berdasarkan uraian di atas, maka peneliti tertarik untuk meneliti mengenai Analisis Faktor yang Memengaruhi Kunjungan Masyarakat dalam Pemanfaatan Posbindu di Wilayah Kerja Puskesmas Singkil Utara Tahun 2019.

\section{BAHAN DAN METODE}

\section{Jenis Penelitian}

Penelitian survei analitik dengan pendekatan cross sectional.

\section{Populasi dan Sampel}

Populasi sebanyak 2.019 orang masyarakat yang sering berkunjung usia di atas 30 tahun di wilayah kerja Puskesmas Singkil Utara. Sampel sebanyak 100 orang

\section{Variabel Penelitian}

Variabel dependen adalah pekerjaan, pengetahuan, sikap, dukungan tenaga kesehatan, dukungan kader, dukungan keluarga dan dukungan tokoh masyarakat/ agama. Variabel independen adalah kunjungan masyarakat dalam pemanfaatan Posbindu.

\section{Metode Pengumpulan Data}

Instrumen penelitian digunakan untuk pengumpulan data penelitian adalah kuesioner dan obsertavasi.

Uji validitas dan reliabilitas dilakukan kepada 30 remaja yang berkunjung ke Posbindu di luar sampel penelitian.

Uji validitas dilakukan untuk menghitung Pearson Product Moment dan reliabilitas menghitung korelasi cronbach alpha.

\section{Analisis Data}

Data kuantitatif dianalisis secara univariat, bivariat menggunakan uji chi square dan multivariat regresi logistik berganda.

\section{HASIL DAN PEMBAHASAN}

\section{Distribusi Data Karakteristik}

Masyarakat berdasarkan umur lebih banyak tergolong umur kurang produktif di atas 40 tahun yaitu 61 orang (61\%), sedangkan umur produktif di bawah 40 tahun yaitu 39 orang $(39 \%)$. Dilihat dari jenis lebih banyak perempuan yaitu 55 orang (55\%) dan laki-laki 45 orang $(45 \%)$. Masyarakat berdasarkan latar belakang pendidikan lebih banyak tamatan Sekolah Menengah Atas (SMA) yaitu 41 orang (41\%), Sekolah Menengah Pertama (SMP) yaitu 33 orang (33\%) dan Sekolah Dsarh (SD) yaitu 26 orang (26\%).

\section{Hasil Analisis Univatiat}

Masyarakat yang berkunjung ke Posbindu lebih banyak tidak memiliki pekerjaan yaitu 54 orang (54\%), berpengetahuan kurang baik yaitu 69 orang $(69 \%)$, bersikap negatif yaitu 54 orang (54\%), tidak mendukung dukungan tenaga kesehatan yaitu 64 orang (64\%), tidak tidak mendapat mendukung kader yaitu 60 orang (60\%), tidak mendukung keluarga yaitu 72 orang $(72 \%)$, tidak mendukung tokoh masyarakat yaitu 71 orang $(71 \%)$. Masyarakat yang berkunjung ke Posbindu lebih banyak tidak memanfaatkan yaitu 53 orang (53\%). 


\section{Hasil Analisis Bivariat}

Terdapat hubungan pengetahuan $(0,001)$, sikap $(0,018)$, dukungan tenaga kesehatan $((0,001)$, dukungan tenaga kesehatan $(0,006)$, dukungan kader $(0,006)$, dukungan keluarga $(0,000)$ dengan nilai $p$ lebih kecil dari 0,05 . Sedangkan pekerjaan dan tokoh masyarakat tidak berhubungan dengan nilai p 0,450 dan 0,409 lebih besar dari 0,05.

\section{Hasil Analisis Multivariat}

Berdasarkan tabel 1 diketahui kelima variabel independen diperoleh nilai $p$ lebih kecil dari 0,05 yaitu pengetahuan $(0,001)$, sikap $(0,018)$, dukungan tenaga kesehatan $(0,001)$, dukungan kader $(0,006)$, dan dukungan keluarga $(0,000)$.

Variabel pengetahuan diperoleh nilai Exp (B) sebesar 3,312, berarti masyarakat yang berpengetahuan baik cenderung 3,312 kali melakukan kunjungan ke Posbindu daripada berpengetahuan kurang baik. Variabel sikap diperoleh nilai Exp (B) sebesar 3,266, berarti masyarakat yang mempunyai sikap positif cenderung 3,266 melakukan kunjungan ke Posbindu daripada memiliki sikap negatif. Variabel dukungan tenaga kesehatan diperoleh nilai $\operatorname{Exp}(\mathrm{B})$ sebesar 4,317, berarti masyarakat mendapat dukungan dari tenaga kesehatan cenderung 4,317 melakukan kunjungan ke Posbindu daripada tidak mendapat dukungan.

Variabel dukungan kader diperoleh nilai Exp (B) sebesar 2,975, berarti masyarakat mendapat dukungan dari kader cenderung 2,975 melakukan kunjungan ke Posbindu daripada tidak mendapat dukungan. Variabel dukungan keluarga diperoleh nilai Exp (B) sebesar 9,150, berarti masyarakat mendapat dukungan dari keluarga cenderung 9,150 melakukan kunjungan ke Posbindu daripada tidak mendapat dukungan.

Hasil uji regresi logisitik berganda diperoleh nilai Overall Percentage $=79 \%$ yang artinya faktor pengetahuan, sikap, dukungan tenaga kesehatan, dukungan kader, dan dukungan keluarga memengaruhi kunjungan dalam pemanfaatan Posbindu sebesar $79 \%$ sisanya $21 \%$ dipengaruhi oleh faktor lain.

Tabel 1. Hasil Uji Multivariat

\begin{tabular}{|c|c|c|c|}
\hline $\begin{array}{l}\text { Variabel } \\
\text { Independen }\end{array}$ & Nilai $B$ & Nilai $p$ & $\operatorname{Exp}(B)$ \\
\hline Pengetahuan & 1,198 & 0,041 & 3,312 \\
\hline $\begin{array}{l}\text { Sikap } \\
\text { Dukungan }\end{array}$ & 1,184 & 0,030 & 3,266 \\
\hline $\begin{array}{l}\text { tenaga } \\
\text { kesehatan }\end{array}$ & 1,463 & 0,009 & 4,317 \\
\hline $\begin{array}{l}\text { Dukungan } \\
\text { kader }\end{array}$ & 1,090 & 0,045 & 2,975 \\
\hline $\begin{array}{l}\text { Dukungan } \\
\text { keluarga }\end{array}$ & 2,214 & 0,001 & 9,150 \\
\hline Constant & $-4,609$ & 0,000 & 0,010 \\
\hline
\end{tabular}

\section{PEMBAHASAN}

\section{Pengaruh Pekerjaan terhadap Kunjungan Masarakat dalam Pemanfaatan Posbindu}

Tidak ada pengaruh faktor pekerjaan terhadap pemanfaatan Posbindu $(p=0,450<p=0,05)$. Hal ini dapat diartikan masyarakat memiliki pekerjaan maupun tidak memiliki pekerjaan belum menjamin datang berkunjung untuk mendapatkan pemeriksaan kesehatan di Posbindu. 
Penelitian ini sejalan dengan hasil penelitian Kurnia (2017) mengatakan bahwa tidak ada hubungan antara pekerjaan responden dengan kunjungan masyarakat usia produktif di Posbindu PTM Puri Praja wilayah kerja Puskesmas Mulyoharjo dengan nilai $p$ 0,139>0,05 (7). Berbeda dengan penelitian Liansyah (2014) didapatkan hasil penelitian bahwa pemanfaatan Posbindu lanjut usia di wilayah kerja Puskesmas Beji dipengaruhi oleh faktor pekerjaan $(0,001)$. Masyarakat yang berkunjung didominasli oleh perempuan daripada lakilaki (8).

Hasil temuan lainnya bahwa masyarakat yang berkunjung tetapi memiliki pekerjaan $(52,2 \%)$. Hal ini mungkin disebabkan pola pikir memiliki yang memiliki pekerjaan yang didukung dengan pendidikan menginginkan suatu pelayanan kesehatan. Menurut pendapat Green bahwa adanya kecenderungan seseorang yang bekerja lebih aktif mencari pelayanan kesehatan dibandingkan dengan yang tidak bekerja, disebabkan karena disamping pengetahuannya lebih tinggi, juga karena mereka lebih mandiri secara ekonomi. Selain itu kegiatan Posbindu diselenggarakan setiap hari libur dengan frekuensi 1 bulan sekali.

\section{Pengaruh Pengetahuan terhadap Kunjungan Masyarakat dalam Pemanfaatan Posbindu}

Ada pengaruh pengetahuan terhadap kunjugan masyarakat dalam pemanfaatan Posinbdu $(p=0,041<p=0,05)$. Hal ini berarti semakin baik pengetahuan masyarakat, maka semakin kuat keinginan untuk berkunjung dalam memanfaatkan Posbindu.

Hasil penelitian ini sejalan dengan penelitian (2011) menjelaskan bahwa masyrakat di RW 07 Desa Kertawangi Kecamatan Cisarua Kabupaten Bandung Barat sebagian besar berpengetahuan baik mengenai posbindu sebanyak $37,7 \%$, berpengetahuan kurang sebanyak $36,1 \%$ dan berpengetahuan cukup sebanyak $26,2 \%$. Ada hubungan antara pengetahuan dengan masyarakat mengenai Posbindu $(\mathrm{p}=0,0001)(9)$.

Faktor pengetahuan masyarakat yang baik mempunyai pengaruh yang besar terhadap peningkatan status kesehatan seseorang, sedangkan pengetahuan yang buruk dapat menyebabkan kegagalan dalam peningkatan status kesehatannya. Dalam mencapai derajat kesehatan, maka diadakan suatu kegiatan seperti Posbindu dengan penyuluhan guna meningkatkan pengetahuan dan derajat kesehatan masyarakat itu sendiri. Dengan pengetahuan masyarakat yang baik dapat memengaruhi seseorang termasuk kesehatan seseorang akan pola hidup terutama dalam motivasi untuk berperan serta dalam pembangunan8.Terbukti dari nilai Exp pengetahuan sebesar 3,312, berarti masyarakat yang berpengetahuan baik cenderung 3,312 kali melakukan kunjungan ke Posbindu daripada berpengetahuan kurang baik.

Perlu adanya peningkatan frekuensi program promosi penyuluhan kepada masyarakat terutama bertempat tinggal jauh dari Posbindu tentang pentingnya Posbindu yang dilaksanakan secara berkesinambungan serta diharapkab lebih ditingkatkan lagi. Selain itu, bagi keluarga diharapkan agar dapat meningkatkan pengetahuan tentang kesehatan dengan cara aktif mengikuti berbagai kegiatan penyuluhan yang ada dilingkungannya

\section{Pengaruh Sikap terhadap Kunjungan Masyarakat dalam Pemanfaatan Posbindu}

Ada pengaruh sikap terhadap kunjugan masyarakat dalam pemanfaatan Posinbdu di Puskesmas Singkil Timur tahun $2019(p=0,030<p=0,05)$. Hal ini berarti semakin kuat sikap masyarakat terhadap kegiatan Posbindu, maka semakin ingin mereka datang berkunjung untuk melakukan pemeriksaan kesehatan.

Hasil penelitian ini sejalan dengan penelitian Lestari (2011) mengatakan bahwa faktor yang berpengaruh terhadap keaktifan kunjungan lansia ke posyandu yaitu umur $\geq 71$ tahun $(\mathrm{OR}: 4,6)$, tidak bekerja $(\mathrm{OR}: 8,1)$, sikap yang baik (OR:3), peran keluarga yang baik $(\mathrm{OR}: 3,2)$. Faktor yang tidak berpengaruh terhadap keaktifan kunjungan lansia ke posyandu yaitu tingkat pendidikan, kondisi sosial ekonomi, akses, peran sosial lansia (10).

Pada umumnya masyarakat memiliki sikap yang kurang baik terhadap pemanfaatan Posbindu. Hal ini disebabkan masyarakat lebih memilih pemeriksaan kesehatan di puskesmas karena memiliki fasilitas yang lebih lengkap dan dapat bertanya langsung tentang penyakit kepada dokter bersangkutan. Sedangkan di Posbindu didukung dengan peralatan apa adanya. 
Berdasarkan nilai Exp (B) sikap diperoleh sebesar 3,266, berarti masyarakat yang mempunyai sikap positif cenderung 3,266 melakukan kunjungan ke Posbindu daripada memiliki sikap negatif. Hal berarti bahwa sikap masyarakat perlu ditingkatkan di masa mendatang untuk meningkatkan kunjungan supaya memanfaatkan pelayanan kesehatan di Posbindu. Upaya ke depan dapat dilakukan dengan merubah sikap masyarakat tersebut dengan melengkapi fasilitas pemeriksaan kesehatan ama halnya dengan fasilitas di puskesmas. Bila menurunkan seorang dokter dalam memberikan pemeriksaan dini gejala penyakit tidak menular kepada masyarakat.

\section{Pengaruh Dukungan Tenaga Kesehatan terhadap Kunjungan Masyarakat dalam Pemanfaatan Posbindu}

Ada pengaruh dukungan tenaga kesehatan terhadap kunjugan masyarakat dalam pemanfaatan Posinbdu $(p=0,009<p=0,05)$. Hal ini berarti semakin dukungan keinginan tenaga kesehatan mengajak masyarakat untuk memeriksakan kesehatan ke Posbindu dapat memperkuat keinginan masyarakat berkunjung ke Posbindu.

Hasil penelitian ini sejalan dengan penelitian Liansyah (2014) didapatkan hasil penelitian pemanfaatan Posbindu lanjut usia di wilayah kerja Puskesmas Beji sebesar 47\% dengan faktor-faktor yang berhubungan dengan pekerjaan $(0,001)$, pendapatan $(0,001)$, dukungan tenaga kesehatan $(0,002)$, dan faktor kebutuhan $(0,000)$. Untuk meningkatkan pemanfaatan Posbindu dapat dilakukan pengelolaan manajemen program kesehatan dengan lebih terencana. Sosialisasi kepada masyarakat tentang fungsi, tujuan dan manfaat program Posbindu, pengadaan sarana pendukung dan pelatihan kader (8).

Dukungan tenaga kesehatan dalam kegiatan Posbindu merupakan dukungan sosial dalam bentuk dukungan informatif, dimana perasaan subjek bahwa lingkungan memberikan keterangan yang cukup jelas mengenai hal-hal yang diketahui. Tenaga kesehatan adalah setiap orang yang mengabdikan diri dalam kesehatan serta memiliki pengetahuan dan keterampilan melalui pendidikan di bidang kesehatan yang untuk jenis tertentu memiliki kewenangan untuk melakukan upaya kesehatan (11).

Dukungan tenaga kesehatan pada umumnya kurang baik sehingga kunjungan Posbindu rendah. Hal ini disebabkan tenaga kesehatan belum melaksanakan tugasnya dalam memberikan informasi tentang jadwal, manfaat dan tujuan penyelenggaraan Posbinidu ke khalayak ramai. Petugas kesehatan hanya menginformasikan pada saat masyarakat datang berkunjung ke puskesmas saja dapat menyebabkan meningkatnya kasus PTM di Wilayah Kerja Puskesmas Singkil Utara.

Berdasarkan nilai $\operatorname{Exp}$ (B) dukungan tenaga kesehatan sebesar 4,317, berarti masyarakat mendapat dukungan dari tenaga kesehatan cenderung 4,317 melakukan kunjungan ke Posbindu daripada tidak mendapat dukungan. Upaya kepala puskesmas dalam meningkatkan kunjungan Posbindu dengan mengoptimalkan tenaga kesehatan sebagai pelayanan kesehatan sekaligus sebagai penyuluh kesehatan di luar jam kerjanya.

\section{Pengaruh Dukungan Kader terhadap Kunjungan Masyarakat dalam Pemanfaatan Posbindu}

Ada pengaruh dukungan kader terhadap kunjugan masyarakat dalam pemanfaatan Posinbdu di Puskesmas Singkil Timur tahun $2019(p=0,045<p=0,05)$. Hal ini berarti semakin giat kader memberikan informasi, membina, memotivasi dan mengajak masyarakat, maka semakin tinggi kunjungan masyarakat melakukan pemeriksaan kesehatan di Posbindu.

Sejalan dengan penelitian Wahyuni (2017) mengatakan bahwa frekuensi lansia yang tidak mengunjungi Posbindu di Wilayah Kerja Puskesmas Ciputat. Kader Posbindu sangat tinggi mencapai $80,4 \%$ dan variabel yang berhubungan dengan kunjungan Posbindu salah satunya adalah dukungan tenaga kesehatan $(0,000)$ dan dukungan kader $(0,000)$ serta teman $(0,000)$ disebabkan sebelum acara kegiatan Posbindu, kader menginformasikan jadwal dan manfaat kegiatan Posbindu kepada lansia (12).

Kader kurang aktif memberikan informasi kesehatan kepada masyarakat sehingga masyarakat belum merata mengetahui keberadaan Posbindu. Kader juga kurang perhatian dalam memberikan layanan kesehatan sehingga masyarakat kurang tertarik datang ke 
Posbindu. Hal ini menyebabkan dukungan kader terhadap kunjungan masyarakat ke Posbindu masih kurang baik dari segi informasi, emosional dan tindakan nyata. Menurut Depkes RI (2005) bahwa kader mempunyai tugas mampu berkomunikasi dengan baik yaitu mampu mengajak dan memotivasi kelompok maupun masyarakat. Kader juga harus mampu membina semua yang terkait dengan Posbindu dan tetap membina semua yang berkaitan dengan Posbindu dan tetap memantau pertumbuhan dan penyakit masyarakat (13).

Berdasarkan nilai nilai Exp (B) dukungan kader sebesar 2,975, berarti masyarakat mendapat dukungan dari kader cenderung 2,975 melakukan kunjungan ke Posbindu daripada tidak mendapat dukungan. Faktor dukungan kader merupakan faktor pentng dalam meningkatkan kunjungan masyarakat ke Posbindu karena selain sebagai pengelola Posbindu dan juga sebagai petugas yang berinteraksi langsung kepada masyarakat sehingga diperlukan kepiawaian dan kemampuan dalam berkomunikasi secara efektif. Kader juga jarang menyelenggarakan kegiatan seperti masak memasak, menyulam bagi perempuan dan senam bagi laki-laki untuk meningkatkan minat masyarakat datang berkunjung. Maka dari itu, perlu di masa mendatang meningkatkan peran kader dengan cara memberikan memberikan pelatihan kepada kader tentang komunikasi efektif dan memberikan penghargaan reward atau penambahan insentif bagi kader yang mampu meningkatkan jumlah kunjungan masyarakat sehingga dapat menjadikan sebagai motivasi dalam bekerja agar lebih giat dan memiliki semangat tinggi dalam menyelenggarakan Posbindu. Kader juga dapat menambah kegiatan-kegiatan lainnya seperti acara masakmemasak dan senam sehat.

\section{Pengaruh Dukungan Keluarga terhadap Kunjungan Masyarakat dalam Pemanfaatan Posbindu}

Ada pengaruh dukungan keluarga terhadap kunjugan masyarakat dalam pemanfaatan Posinbdu $(p=0,001<p=0,05)$. Hal ini berarti semakin baik pengetahuan masyarakat, maka semakin kuat keinginan untuk berkunjung dalam memanfaatkan Posbindu.

Hasil penelitian ini sejalan dengan penelitian Umayana (2015) mengatakan distribusi responden berdasarkan keaktifan penduduk diketahui bahwa responden yang tidak aktif sebanyak 135 orang $(52,3 \%)$ dan responden yang aktif sebanyak 123 orang $(7,8 \%)$. Faktor dukungan keluarga ( $p$ value $=0,0001$ ) dan dukungan tokoh masyarakat ( $p$ value $=0,001$ ) berhubungan dengan keaktifan penduduk ke kegiatan posbindu PTM di Kota Semarang (14).

Hasil temuan di lapangan menjelaskan bahwa keluarga belum menyediaan perhatian dan ketulusan dalam membantu anggota keluarga lainnya dalam memanfaatkan Posindu. Kepala keluarga tidak menginformasikan dan memberikan penjelasan tentang manfaat yang dirasakan terhadap pemeriksaan kesehatan, manfaata mengikuti konseling dan penyuluhan tentang PTM serta membujuk anggota keluarga mengikuti kegiatan Posbindu. Menurut Friedman (2008) mengatakan peran keluarga meningkatkan kesehatan dapat dilakukan dengan cara meningkatkan dukungan emosional, penghargaan, instrumen dan informatif yang diberikan oleh anggota keluarganya (15).

Jika dinilai dari besaran nilai Exp (B) yaitu 9,150, berarti masyarakat mendapat dukungan dari keluarga cenderung 9,150 melakukan kunjungan ke Posbindu daripada tidak mendapat dukungan. Variabel dukungan keluarga penting ditingkat di masa mendatang karena merupakan faktor dominan untuk meningkatkan kunjungan Posbindu dengan melakukan penyuluhan pada kegiatan-kegiatan keagamaan dan sosial lainnya untuk meningkatkan pemahaman dan manfaat program PTM sehingga timbul minat masyarakat berkunjung ke Posbindu.

\section{Pengaruh Dukungan Tokoh Masyarakat terhadap Kunjungan Masyarakat dalam Pemanfaatan Posbindu}

Tidak ada pengaruh dukungan tokoh masyarakat terhadap kunjugan masyarakat dalam pemanfaatan Posinbdu di Puskesmas Singkil Timur tahun 2019 ( $p=0,0,409<p=0,05)$. $\mathrm{Hal}$ ini berarti semakin baik pengetahuan masyarakat, maka semakin kuat keinginan untuk berkunjung dalam memanfaatkan Posbindu.

Hasil penelitian ini sejalan dengan penelitian Purnawati (2014) menjelaskan bahwa faktor yang memengaruhi kunjungan lansia ke posyandu yaitu pengetahuan yang baik, sikap yang baik, dan akses yang baik, dan dukungan masyarakat yang baik dengan nilai $p<0,05$ di Desa Plumbon, Kecamatan Mojolaban Sukoharjo (16). 
Menurut Trihardini bahwa perilaku mengikuti posbindu PTM sangat efektif bila didukung oleh situasi sosial yang baik. Keluarga, teman dekat, teman kerja, dan lingkungan sekitar merupakan komponen penting dari terbentuknya perilaku seseorang dalam mengikuti pelayanan kesehatan dalam posbindu PTM (17).

Hasil temuan di lapangan dukungan tokoh masyarakat dalam mensukseskan kunjungan Posbindu yang diselenggarakan di setiap desa kurang baik. Hal ini terlihat dari jawaban masyarakat mengatakan bahwa tokoh masyarakat kurang aktif memberikan informasi dan kegiatan Posbindu dan jarang mengikuti kegiatan tersebut. Tokoh masyarakat juga kurang aktif memfasilitasi fasilitas kegiatan Posbindu dan bantuan dana sehingga kegiatannya kurang menarik jika dilihat dari pandangan masyarakat.

Temuan penelitian didapat bahwa dukungan tokoh masyarakat kurang baik dalam meningkatkan kunjungan masyarakat di Posbindu disebabkan umpan balik yang diterima tokoh masyarakat dari kegiatan Posbindu kurang dirasakan karena kegiatan Posbindu sifatnya sukarela dan tanpa paksaan sehingga tidak ada unsur paksaan apakah ingin berpartispasi atau tidak.

\section{KESIMPULAN DAN SARAN}

\section{Kesimpulan}

a. Masyarakat yang berkunjung dalam memanfaatkan Posbindu, baik yang bekerja dan tidak bekerja tidak menjamin keinginan masyarakat melakukan pemeriksaan deteksi dini PTM. Faktor pendidikan tidak berpengaruh terhadap kunjungan dalam pemanfaatan Posbindu.

b. Pengetahuan masyarakat tentang pelayanan Posbindu kurang baik dan berpengaruh terhadap kunjungan dalam pemanfaatan Posbindu untuk melakukan pemeriksaan PTM.

c. Sikap masyarakat dalam memanfaatkan Posbindu tergolong negatif, dimana merasa kegiatan Posbindu kurang menarik dan berpengaruh terhadap kunjungan dalam pemanfaatan Posbindu untuk melakukan pemeriksaan PTM.

d. Dukungan tenaga kesehatan dari segi informatif, emosional dan tindakan nyata belum mampu meningkatkan kunjungan masyarakat dalam memanfaatkan Posbindu, dan berpengaruh terhadap kunjungan dalam pemanfaatan Posbindu.

e. Dukungan kader dari segi informatif, emosional dan tindakan nyata belum efektif sehingga kunjungan masyarakat ke Posbindu masih rendah, dan berpengaruh terhadap kunjungan dalam pemanfaatan Posbindu.

f. Dukungan keluarga dari segi informatif, emosional dan tindakan nyata belum dapat mengubah persepsi angggota keluarga lainnya agar memanfaatkan Posbindu untuk mendeteksi dini PTM dan berpengaruh terhadap kunjungan dalam pemanfaatan Posbindu.

g. Dukungan tokoh masyarakat dari segi informatif, emosional dan tindakan belum terlaksana secara maksimal sehingga kunjungan masyarakat ke Posbindu masih rendah dan berpengaruh terhadap kunjungan dalam pemanfaatan Posbindu.

\section{Saran}

a. Diharapkan Puskesmas Singkil Utara menyelenggarakan pelatihan tengang komunikasi kepada kader secara kontrinyu yang difasilitasi oleh kepala desa dan memberikan penghargaan (reward) dan meningkatkan insentif sebagai bentuk motivator agar lebih giat dan semangat bekerja untuk meningkatkan kunjungan masyarakat ke Posbindu.

b. Diharapkan Puskesmas Singkil Utara membantu dalam mendukung fasilitas kesehatan dalam deteksi dini PTM 
c. Kader diharapkan memberikan penyuluhan tentang program PTM secara kontinyu ke seluruh desa terutama pada saat kegiatan keagamaan dan sosial lainya serta mencari tokoh masyarakat yang mau secara sukarela membantu memfasilitasi kegiatan Posbindu.

d. Kader juga diharapkan dapat menambah berbagai kegiata-kegiatan lainnya seperti masak-memasak dan senam saat menyelenggaraan Posbiindu untuk meningkatkan ketertarikan masyarakat.

e. Kepala keluarga diharapkan mampu mengubah persepsi anggota keluarga lainnya agar bermnat berkunjung dengan terlibat dan mau berpartisipasi mengikuti kegiatan Posbindu.

\section{DAFTAR PUSTAKA}

1. WHO. Global Status Report on Non Communicable Diseases 2010. Geneve, Switzerland: WHO; 2011.

2. Kemenkes RI. Riset Kesehatan Dasar Tahun 2013. Badan Penelitian dan Pengembangan Kesehatan. Jakarta; 2013.

3. Kemenkes RI. Petunjuk Teknis Pos Pembinaan Terpadu Penyakit Tidak Menular. Dirjen Pengendalian Penyakit dan Penyehatan Lingkungan dan Direktorat Pengendalian Penyakit Tidak Menular. Jakarta; 2014

4. Dinas Kesehatan Kabupaten Aceh Singkil. Profil Dinas Kesehatan Kabupaten Aceh Singkil. Singkil; 2017

5. Handayani DE. Pemanfaatan Pos Pembinaan Terpadu oleh Lanjut Usia di Kecamatan Ciomas Kabupaten Bogor dan Faktor yang Berhubungan. Skripsi. [Internet]. [cited] 2012. Tersedia di: http://lontar.ui.ac.id/file? file=digital/20300600-S42008-Dewi\%20Eka\% 20Hand ayani.pdf.

6. Green LW. Health Education Planning: a Diagnostic Approach. (4st edition). California: Mayfield Publishing Company; 2005.

7. Kurnia AR. Analisis Faktor yang Berhubungan dengan Kunjungan Masyarakat Usia Produktif (15-64 Tahun) di Posbindu PTM Puri Praja Wilayah Kerja Puskesmas Mulyoharjo,Pemalang. Tesis. [Internet]. [cited] 2017. Tersedia di: http://eprints.undip.ac.id/58188/.

8. Liansyah W. Faktor-faktor yang Berhubungan dengan Pemanfaatan Pelayanan Posbindu Lansia di wilayah kerja Puskesmas Beji. Skripsi. [Internet]. [cited] 2014. Tersedia di: http://www.lib.ui.ac.id/naskahringkas /2016-05/S55555-Wahyu\%20Liansyah.

9. Septriliyana, R.N, dan Sari WE. hubungan pengetahuan dengan sikap lansia mengenai Posbindu di RW 07 Desa Kertawangi Kecamatan Cisarua Kabupaten Bandung Barat. Skripsi. [Internet]. [cited] 2011. Tersedia di: http:// stikesayani.ac.id/publikasi/ejournal/filesx/2011/201108/201108-006. pdt.

10. Lestari H. dan Pranaka. Beberapa Faktor yang Berperan terhadap Keaktifafn Kunjungan Lansia ke Posyndu Studi Kasus di Detamantirto Kecamatan Kasihan. Kabupaten Bantul. Jurnal Media Medika Indonesia. 2011.45 (2): 74-82.

11. Nuswantari, Dyah. Kamus Kedokteran Dorland Edisi 25. Jakarta: EGC; 1998.

12. Wahyuni DN. Faktor-faktor yang Berhubungan dengan Kunjungan Pos Pembina Terpadu (Posbindu) pada Lansia di Wilayah Kerja Puskesmas Ciputat. Skripsi. [Internet]. [cited] 2018. Tersedia di: http://repository.uinjkt. ac.id/dspace/bitstream/123456789/37758/1/DESY\%20NUR\%20WAHYUNI-FKIK.pdf. 
13. Depkes RI. Buku Panduan Kader Posyandu. Jakarta; 2005.

14. Umayana HT dan Cahyati WH. Dukungan Keluarga dan Tokoh Masyarakat terhadap Keaktifan Penduduk le Posbindu Penyakit Tidak Menular. Jurnal Kemas. 2015. 11 (1): 96-101.

15. Friedman \& Marilyn. Keperawatan Keluarga: Teori dan Praktik (Edisi 3). Jakarta: EGC; 2008.

16. Purnawati N. Faktor-Faktor yang Mempengaruhi Kunjungan Lansia dalam Kegiatan Posyandu di Desa Plumbon Kecamatan Mojolaban Sukoharjo. Skripsi. [Internet]. [cited] 2014. Tersedia di: http://eprints.ums.ac.id/30723/17/Naskah Publikasi Deal.pdf.

17. Trihardini I. Potret Buram Pelayanan Kesehatan Lanjut Usia di Indonesia, KESMAS; 2007. 1: (5). 